

\title{
MERGER WAVES AND THE AUSTRIAN BUSINESS CYCLE THEORY
}

\author{
Jimmy A. Saravia ${ }^{1}$
}

November $5^{\text {th }}, 2013$

\begin{abstract}
Following standard Austrian School theory, in this paper I identify merger waves as parts of Austrian type business cycles. As indicated by Mises, Rothbard and Hayek, when loan rates are reduced below their natural level through bank credit expansion this falsifies the monetary calculation of capitalist-entrepreneurs. As a result, new investments are initiated that calculation showed were not profitable before the interest rate reduction. On the other hand, the fall in interest rates falsifies households' appraisals of their income and wealth, which turns them overly optimistic and causes them to over-consume, save less and go into debt. As a consequence of these developments the economy does not have enough resources for the completion of the new projects and businesses must increasingly withdraw the resources from other companies. I conclude that the increase in investment activity and the accompanying "resource crunch" cause a merger wave that helps prolong the boom phase of the cycle. The merger wave ends when the credit expansion is not sufficient to sustain the economic boom (which usually occurs when central banks finally let interest rates rise again and an overextended financial system tightens credit standards) and the bust phase begins. On the other hand, if the newly created fiduciary media does not enter the economy through the loan market to finance business investment, there should be no pronounced and sustained increase in merger activity followed by an economic bust.
\end{abstract}

KEYWORDS: Austrian business cycle, merger waves, Austrian, Neoclassical, Behavioral JEL CLASSIFICATION: B53, E32, G34

\section{INTRODUCTION}

One of the main puzzles in contemporary mainstream financial economics is: why are there time periods of frantic Mergers and Acquisitions (M\&A) activity known as merger waves? While in this literature much work has been done on the causes of takeovers and restructuring activity at the firm and industry level, relatively little work has been done on

\footnotetext{
${ }^{1}$ Professor, Grupo de Investigación en Banca y Finanzas, School of Economics and Finance, Center for Research in Economics and Finance (CIEF), Universidad EAFIT, Carrera 49 Número 7 Sur 50, Medellín, Colombia, e-mail: jsaravia@eafit.edu.co.
} 
the causes of economy wide merger waves. Moreover, the latter is divided in two rival camps: behavioral and neoclassic.

According to the "behavioral hypothesis" of merger waves during bull markets investors irrationally misprice stocks across the board and rational managers, taking advantage of misperceived merger synergies, use their overvalued stock to acquire the resources of less overvalued or undervalued companies. The main proponents of this theory are Shleifer and Vishny (2003). On the other hand, the “neoclassical hypothesis” maintains that merger waves are rational responses by market participants that occur when economic shocks (economic, regulatory, or technological) which call for industrial reorganization, overlap with low transaction costs that take place because of the presence of high "capital liquidity”. Where, the role of capital liquidity is to reduce the costs of reallocating the assets thus permitting a large volume of transactions to occur in a relatively short period of time. The main proponent of the neoclassical theory is Harford (2005). ${ }^{2}$

From an Austrian perspective, however, the causes proposed by these two schools (i.e. overvaluation of stocks or economic shocks followed by high capital liquidity which reduces transaction costs) cannot be accepted as ultimate causes of merger waves. Although these factors may plausibly have an influence in the direction of the actual market process during an economic boom and the accompanying merger wave, the causes of their occurrence can be explained in turn at a more basic level in the context of the Austrian Business Cycle Theory (ABCT).

\footnotetext{
${ }^{2}$ There is a growing body of empirical literature that aims to test the hypotheses of the neoclassical and behavioral schools which has yielded mixed results. Some of the relevant work includes Rhodes-Kropf et al. (2005), Dong et al. (2006), Gärtner et al. (2009) and Gugler et al. (2012).
} 
Following standard Austrian theory step by step, in this paper I identify merger waves as parts of Austrian Business Cycles. The argument is briefly as follows: when bank credit expansion reduces loan rates below their natural level, capitalist-entrepreneurs ${ }^{3}$ will tend to undertake more investments than can be completed with the resources available in the economy. The initiation of these projects launches an unsustainable economic boom, and due to the escalating scarcity of resources aggravated by household overconsumption, businesses must increasingly withdraw the resources from other companies. I conclude that this increase in investment activity together with the accompanying "resource crunch" causes the merger wave. If this logical deduction is correct, then the two standard theories in mainstream financial economics mentioned above are leaving out important causes of the merger wave such as the increase in investments and the scarcity of resources during the economic boom. Also note that in this context, the phenomenon of stock overvaluation highlighted by the behavioral school can be explained, as a result of the reduction of interest rates (when interest rates are artificially pushed downwards asset prices will tend to artificially increase), and also as a result of the increased demand for the resources that the stocks give title to. On the other hand, the high "capital liquidity" pointed out by the neoclassical school is explained in the context of ABCT as a result of bank credit expansion. ${ }^{4}$

The rest of this paper is organized as follows: in section 2 I briefly go over the main arguments of ABCT and indicate how merger waves rise and wane. In section 3, I provide

\footnotetext{
${ }^{3}$ The capitalist-entrepreneurs are "the speculators, promoters, investors and money lenders" who determine "the structure of the stock and commodity exchanges and of the money market" and the "allocation of capital to firms and industries." See Mises (1998, p. 704) and Rothbard (1991, p. 58).

${ }^{4}$ Theoretical variations on the neoclassical and behavioral themes are provided by Jovanovic and Rousseau (2002), Rhodes-Kropf and Viswanathan (2004) and Gugler et al. (2012). However, since these theories are susceptible to the same critique above I do not consider it necessary to discuss them here.
} 
an illustration of the theory by examining the history for the United States in the last 20 years. In particular, I draw attention to the fact that when fiduciary media entered the economy through the loan market to finance business investment, Austrian Business cycles accompanied by merger waves occurred, but that when newly created money did not enter the economy through the loan market to finance business investment, there was no pronounced and sustained spike in merger activity although stock prices and liquidity were at historic highs. I conclude in section 4 by summing up and reinterpreting some of the findings of the behavioral and neoclassical schools in light of the Austrian theory.

\section{MERGER WAVES AS PART OF ABCT}

According to the ABCT the business cycle is caused by a reduction of the interest rate below its natural level when newly produced fiduciary media, created by the financial system, enters the economy through the loan market and falsifies the monetary calculation

of capitalist-entrepreneurs and households (Mises, 1998; Hayek, 2008; Rothbard, 2009). This artificial reduction in the rates of interest has two effects which constitute the essential features of the Austrian Business Cycle: “malinvestment” and “overconsumption” (Salerno, 2012).

On the one hand, the artificial reduction of interest rates leads capitalist-entrepreneurs to believe that society has become thriftier and that the level of savings has increased, when in fact the interest rate is too low in comparison with society’s time preference. This in turn prompts them to overestimate the amount of resources available to invest and to begin more projects than can be finished with the available means of production. Moreover, the proportion of longer term projects will increase relative to short term projects as their 
present value will increase more due to the interest rate reduction, and as a consequence the structure of production is lengthened. This unsustainable lengthening of the structure of production constitutes the malinvestment feature of the inflationary boom. On the other hand, the fall in interest rates also falsifies households' appraisals of their income and wealth. This comes about through what is called the "wealth effect". As the inflationary boom proceeds and factors of production become more scarce, salaries are bid up and asset prices (such as stocks and real state) also go higher (Bagus, 2008). Thus households feel wealthier and more optimistic about their future income streams. This causes them to overconsume, save less and even go into debt as they mistakenly believe they can afford it. This constitutes the overconsumption aspect of the Austrian Business Cycle (Salerno, 2012).

Overconsumption aggravates even more the erroneous assessment regarding the availability of investable resources made by the capitalist-entrepreneurs, and the scarcity of all kinds of resources eventually becomes evident as prices for those resources start to soar. As businesses increase their demands from the several resource and labor markets, these ultimately become depleted and the resources, if available, of relatively lower quality and expensive. Therefore, firms must increasingly withdraw resources from other companies.

As pointed out by Klein (1999) company managements supplement their normal forms of investment (i.e. capital expenditures and R\&D) by purchasing the assets of existing firms through merger. Thus, as investment activity increases in the earlier stages of the boom, it is logical to deduce that merger activity will increase as well, and this initiates the merger wave. However, as mentioned above the economy’s resources are not sufficient to complete all the projects. Thus the question that capitalist-entrepreneurs and their managements ultimately face is: what can be done to finalize the investments or at least to continue them 
one more period of time? Clearly, if resources are scarce and costly, it should become easier for capitalist-entrepreneurs and firm managements to see the operating economies that can result from eliminating duplicate facilities, and consolidating the marketing, purchasing and accounting operations. On the other hand, during the boom synergy and economy of scale stories are easier to make and back with numbers. For example, a company that increases its productive capacity may find its sales force inadequate and that synergies can be achieved by merging with another firm with a strong sales force. Thus, in order to complete the projects one solution can be either to purchase another company or sell your own firm to a business that has the resources to complement your investments. In addition, this would also have the advantage of reducing the number of firms competing for the same pool of resources.

I conclude that, facing a "resource crunch," businesses must increasingly find it advantageous to merge with other companies. Therefore, during the inflationary boom one should expect to see both, an exceptionally high demand of resources in the different markets (manifested, for example, in a very low unemployment rate and high resource prices) and an unusually high level of M\&A activity. Interestingly, this also explains why past economic booms have seemed to last longer than one would expect if companies could only draw their factors of production from the different resource and labor markets. By taking their resources from other companies through merger, capitalist-entrepreneurs and their managements can carry out their projects for one more period of time.

In this context, the economic, regulatory and technological shocks proposed by the neoclassical literature (Harford, 2005) have a role in determining in which industries the merger wave is more pronounced. In particular, as Callahan and Garrison (2003, p. 74) 
have pointed out "every bubble needs a story, which early investors can tell to later ones to justify rising asset prices” and it is clear that technological innovation such as the internet in the 1990s and episodes of deregulation can serve this purpose. This is not to deny that an economic, regulatory or technological shock can prompt a legitimate reallocation of assets in an industry. Austrian Theory demonstrates that, in the absence of bank credit expansion, capitalist-entrepreneurs relying on sound monetary calculation would proficiently undertake the reallocation of assets over time with some occasional errors, but nothing in the way of a manic episode with a clustering of entrepreneurial error ending in an economy wide crisis. The important point is that, in a monetary regime in which bank credit expansion is allowed, the merger wave should be more pronounced in those industries where there is a good story to justify the high asset prices. And a convincing economic, regulatory or technological shock can provide such a narrative.

The merger wave ends with the Austrian type business cycle, when the credit expansion is not sufficient to sustain the economic boom, which usually occurs when central banks finally detect in their aggregate measurements that price inflation is increasing sharply. At this point the authorities have two options, to continue stimulating the economy and risking a “crack-up boom” (Mises, 1998), or tighten monetary policy and let interest rates rise again. If the latter option is chosen, the overextended financial system becomes increasingly concerned as the errors committed in the boom become evident, credit standards are tightened and the crisis begins. As a result, consumption and investment plummet, unemployment rises and M\&A activity falls.

Finally, it is important to point out that if the newly created fiduciary media does not enter the economy through the loan market to finance business investment and distort the 
structure of production, there is no Austrian type boom-bust cycle. If so, there should be no pronounced and sustained spike in merger activity and the accompanying clustering of entrepreneurial error.

\section{HISTORICAL ILLUSTRATION}

In this section I provide an illustration of the Austrian merger wave theory elaborated in this paper by examining the history for the United States in the last 20 years. During this period Austrian economists and commentators successfully identified and warned in advance about the boom and the subsequent bust of two Austrian type business cycles developing in the U.S. economy (Thornton, 2013). Moreover, after each of the busts Austrian economists such as Callahan and Garrison (2003) and Salerno (2012) provided detailed accounts about the two episodes as well as commentaries about the prospects for the future. Hence, in what follows I take it as an established historical fact that there occurred two Austrian type business cycles in the period under question, and therefore, my focus will be in indicating how merger waves were a part of these boom-bust cycles.

First Business Cycle (from 1995 to 2002). According to Callahan and Garrison (2003), the first business cycle in the relevant period occurred between 1995 and 2002. In their paper, the immediate cause of the cycle is identified as the loose monetary policy of the FED prior to the 1996 presidential elections. The Asian Crisis of 1997, the subsequent Russian default, the Long Term Capital Market (LTCM) crisis and the Y2K scare forced the FED to continue with its expansive monetary stance through early 2000, even though the economy was showing signs of overheating. The resultant low interest rates and fiduciary media created by the financial system falsified the capitalist-entrepreneurs 
monetary calculation which in turn started to malinvest notably in dot-com and telecommunication companies, but also in other sectors of the economy. Figure 1 shows the high levels of net private investment during the boom. Here I take net investment rather than gross investment given that the former is a measurement of expenditure in excess of that required to maintain the existing capital structure. As can be seen net investment peaked in 2000 .

[Insert Figure 1 here]

The monetary stimulus also resulted in overall high stock prices which peaked in March of 2000 (Figure 2) and through the "wealth effect" induced households to overconsume, produced a collapse in savings and an increase in household indebtedness. In particular, households reduced their personal savings rate from around 9\% in the early 1990s to 4\% in 1999-2000 (Figure 3). Additionally, the increase in indebtedness is reflected in the increment in debt service payments as a percent of personal disposable income which increased from $11 \%$ to close to $13 \%$ in the 1990 s (Figure 4).

\author{
[Insert Figure 2 here] \\ [Insert Figure 3 here] \\ [Insert Figure 4 here]
}

Crucially, the capital consumption and malinvestment resulted in a shortage of resources and workers in the different industries. In their paper, Callahan and Garrison (2003, p. 87) draw attention to the scarcity of resources in the dot-com sector: 
There were too few resources available for all of the plans formulated and funded during the boom to succeed... There were shortages of programmers, network engineers, technical managers, office space, housing for workers, and other factors of production.

Finally, Callahan and Garrison indicate that the business cycle ended when FED tightened monetary policy in 2000 and punctured the bubble. As a result, an economic recession ensued and the 1990s boom came to an end.

I conclude from the foregoing that as investment activity increased in the earlier stages of the boom (Figure 1), merger activity also increased as company managements supplemented their normal forms of investment (i.e. capital expenditures and R\&D) by purchasing the assets of existing firms through merger. This initiated the merger wave. Moreover, I deduce that the "resource crunch" described by Callahan and Garrison (2003) intensified the merger wave of the late 1990s and allowed the boom to persist for a while. Clearly, resources were scarce and costly, and in order to complete the projects capitalistentrepreneurs and their managements had only two solutions: either to purchase another company and use the resources contained in therein, or sell the firm to a business that has the complementary resources to bring the project to fruition lest the enterprise results in a total loss. In this context, the usual justifications for mergers such as operating economies, synergies and economies of scales can be backed using (falsified) economic calculation. Finally, the merger wave ended when the bust set in and the errors committed during the boom became manifest to most economic actors (e.g. the evident overcapacity in the telecommunications industry). As a result some of the investments lost most of their value and others had to be liquidated. 
The merger wave is illustrated in Figures 5 and 6. As can be seen the value of completed M\&A transactions during the period of the boom-bust cycle described by Callahan and Garrison (2003) tripled from around \$600 billion in 1995 to $\$ 1800$ billion in 2000 and then fell considerably to slightly over $\$ 500$ billion in 2002 once the bust set in. This is also, reflected in the number of completed M\&A transactions which increased from slightly over 9,000 in 1995 to over 12,800 in 1998 and then fell to 7,400 in 2002.

\section{[Insert Figure 5 here]}

[Insert Figure 6 here]

Second Business Cycle (from 2002 to 2009). The second Austrian type business cycle in the period under study occurred between 2002 and 2009 and is described in detail by Salerno (2012). The author describes how the FED reacted immediately to the recession of the early 2000s by aggressively lowering interest rates and taking measures to expand the money supply. Notably, the FED kept the Federal Funds rate under 2 percent for three years from December 2001 to November 2004. More importantly, there was a sharp reduction in 30 year conventional mortgage rates and adjustable mortgage rates, which combined with loose credit standards resulted in a housing bubble (during which housing prices were registering double-digit annual increases) that peaked in 2006. The monetary stimulus also caused a steep ascent in stock prices which continued go up until 2007 (Figure 2). These developments created a "wealth effect" that led households to overconsume and go into debt, as stated by Salerno (2012, p. 30):

Misled by their inflation-bloated balance sheets, households were induced to "cash out" some of their home equity and increase expenditures on consumer goods and services. In 
the expression of the day, people began "using their homes as ATM machines.” Households financed their increased spending on boats, luxury autos, upscale restaurant meals, pricy vacations etc., through fixed-dollar debt.

The wealth illusion also produced a reduction in saving. As shown in Figure 3, the personal saving rate as a percent of disposable income fell from slightly over $5 \%$ in early 2002 to $2 \%$ in 2005.

On the other hand, the extent of the malinvestments during the 2002-2009 boom-bust cycle is illustrated in Figure 1. As can be seen, after falling to $\$ 538$ billion in 2002, net private domestic investment resumed its growth and reached a peak at \$848 billion in 2006. As in the previous cycle, the boom came to an end as the FED raised interest rates. On this occasion, the errors committed during the boom became dramatically manifest in the housing market. This had dire implications for the financial system as most of the housing investors were highly levered with bank credit and their mass defaults brought the prospect of the failure of many banks. This in turn triggered bank runs and financial instability which, according to reports in the mainstream media, prompted the Federal Government and the Federal Reserve to take unprecedented measures to prevent a financial collapse.

Importantly, in this second boom-bust cycle it is possible to discern the same pattern in M\&A activity. As investment activity started to pick up again in 2003 (Figure 1), M\&A activity also started to increase as company managements supplemented their investments in R\&D and capital expenditures with mergers and acquisitions (Figures 5 and 6). Moreover, as the overconsumption described by Salerno (2012) and net private investment intensified, another "resource crunch" situation developed, which intensified the merger 
wave. The mergers allowed the boom to temporarily continue for a while. The merger wave ended when as the FED tightened monetary policy triggering the bust.

As shown in Figure 5, the value of completed M\&A transactions more than tripled from $\$ 506$ billion in 2002 to $\$ 1688$ billion in 2007 and then almost halved to $\$ 854$ billion in 2009. The merger wave is also reflected in the number of completed M\&A transactions (Figure 6), which increased from 7,460 in 2002 to 12,394 in 2007 and then fell to 7,873 in 2009.

Economic stagnation (from 2009 to ...). Following the financial crisis, the FED reacted aggressively with a series of Quantitative Easing (QE) programs that have boosted the monetary base at an unprecedented rate (Figure 7). In addition, the FED reduced the Federal Funds rate to close to zero percent in December 2008 where they have been kept and are expected to be maintained for the foreseeable future, and has taken steps to bring down long term interest rates as well (the so-called "Operation Twist”).

\section{[Insert Figure 7 here]}

Although these measures have succeeded in re-inflating stock market price indices which have recently reached historic highs (Figure 2), on this occasion the stimulus has failed to restore the growth of bank credit expansion to the double-digit annual growth rates observed during the last two business cycles (Figure 8), and net private domestic investment has remained depressed with the 2012 figure 60 percent below the 2006 high of \$849 billion (Figure 1).

[Insert Figure 8 here] 
Thus in the period after the financial crisis, the newly created money has not entered the economy through the loan market to finance business investment. Instead the money has been flowing to the financial markets to inflate the prices of financial assets and to finance trillion dollar Federal Government deficits. In contrast, households have started to save more with the personal savings rate increasing from around 2 percent before the latest recession to between 4 to 6 percent for most of the period after the crisis (Figure 3).

Now, if the newly created money is not entering the economy through the loan market to finance business investment to distort the structure of production, there can be no boombust cycle of the Austrian type. Instead, Austrian theory indicates that there will be price inflation and wealth redistribution from the productive classes of society to those best placed to take advantage of the consequences of the inflation. Moreover, as pointed out in section 2 above, if there is no Austrian business cycle developing there ought not to be a pronounced and sustained spike in M\&A activity followed by a crisis that reveals a cluster of investment errors on the part of capitalist-entrepreneurs.

Interestingly, contrary to the predictions of the neoclassical and behavioral theories of merger waves, in a period such as the one at hand in which capitalist-entrepreneurs have temporarily lost their confidence in the reliability of economic calculation (Salerno, 2012) and regime uncertainty is high (Higgs, 1997; Id., 2012), there should be no merger wave even though (a) stock prices are being inflated to record highs through monetary policy (conflicting with the behavioral theory), and (b) strong economic shocks and dislocations overlap with unprecedented levels of liquidity in the stock markets (opposite to the neoclassical theory). 
This conclusion of no merger wave without Austrian type business cycle is consistent with the history of M\&A activity in the period after the financial crisis. As shown in Figure 5, after falling to $\$ 850$ and $\$ 890$ billion in 2009 and 2010 respectively there was a "dead cat bounce” in the value of completed M\&A activity in 2011 to $\$ 1,100$ billion before falling back again to $\$ 835$ billion in 2012. All of these figures are between 35 to 50 percent lower than the high reached in the previous cycle of $\$ 1,688$ billion in 2007 , so there are no signs of a merger mania when examining the value of M\&A activity after the financial crisis. Additionally, Figure 6 shows that a pronounced spike in the number of completed M\&A transactions has also not occurred, after falling to 7,873 deals in 2009 , the number of transactions has gradually increased to 9,107 in 2012 , this latter number still $26 \%$ below the 12,394 figure reached in 2007.

\section{CONCLUSION}

The phenomenon of the business cycle, their accompanying merger waves and the economic impoverishment they bring are not a feature of the free market as many economists have uncritically assumed. Instead, as the Austrian school maintains, these phenomena are the result of the way in which the monetary and banking system have been historically organized. To prevent business cycles and merger waves the solution would involve a reform in which the reduction of interest rates below their natural level through bank credit expansion is ruled out.

Once an Austrian type boom-bust cycle is under way, the behavioral school is correct, I believe, in that some of the M\&A activity will occur as managers, taking advantage of misperceived merger synergies, use their overvalued stock to acquire the resources of less 
overvalued or undervalued companies. However, the cause of the radical mispricing of the stocks are not some mysterious "animal spirits", rather it is the result of the falsification of the households' and capitalist-entrepreneurs' monetary calculation. This suggests that in addition to studying human behavior under uncertainty, behavioral economists should also study human behavior under false information about their wealth, income and investment prospects.

On the other hand, the neoclassical school has a point in indicating that economic, technological and regulatory shocks and excessive liquidity have a role in merger waves. However, in the context of the ABCT the role of the shocks is to provide a story to justify the bubble as Callahan and Garrison (2003) have pointed out. In this sense, the bubble will tend to be more pronounced in those sectors where a more credible case for the high prices can be made. Moreover, the excess liquidity is not something that just happens cyclically and endogenously in the free market. Instead it is the result of the monetary intervention and the bank credit expansion that existing institutional arrangements allow. On the other hand, the neoclassical school is too sanguine in supposing that virtually all economic activity that takes place in the real world is an optimal response to some disturbance and that capitalist-entrepreneurs are basically omniscient and never make mistakes. In fact, capitalist-entrepreneurs do make mistakes and under free market capitalism with sound money entrepreneurs would still make some mistakes evenly over time. What needs explanation is why entrepreneurial mistakes tend to cluster and are identified at some points in time called recessions, and I submit that ABCT is our best explanation of why these clusters of entrepreneurial mistakes occur. 
Ultimately, from the perspective of the Austrian school, the behavioral and neoclassical schools do not identify the underlying causes of merger waves. Although the factors proposed may plausibly have an influence in the direction of the actual market process during an economic boom and the accompanying merger wave, the causes of their occurrence can be explained a more basic level in the context of ABCT. Financial economists would do well to incorporate the insights of the Austrian school in their work; many of the puzzles of modern finance could be solved in this way.

\section{REFERENCES}

Bagus, Philipp. 2008. “Monetary Policy as Bad Medicine: The Volatile Relationship between Business Cycles and Asset Prices.” Review of Austrian Economics 21, pp. 283-300.

Callahan, Gene, and Roger W. Garrison. 2003. "Does Austrian Business Cycle Theory Help Explain the Dot-Com Boom and Bust?” The Quarterly Journal of Austrian Economics 6, pp. 67-98.

Dong, Ming, David Hirshleifer, Scott Richardson, and Siew Hong Teoh. 2006. “Does Investor Misvaluation Drive the Takeover Market?” The Journal of Finance 61, pp. 725-762.

Gärtner, Dennis L., and Daniel Halbheer. 2009. “Are There Waves in Merger Activity After All?” International Journal of Industrial Organization 27, pp. 708-718. 
Gugler, Klaus, Dennis C. Mueller, and Michael Weichselbaumer. 2012. “The Determinants of Merger Waves: An International Perspective.” International Journal of Industrial Organization 30, pp. 1-15.

Harford, Jarrad. 2005. “What Drives Merger Waves?” Journal of Financial Economics 77, pp. 529-560.

Hayek, Friedrich A. 2008. Prices and Production and other Works. Auburn, Ala.: Ludwig von Mises Institute.

Higgs, Robert. 1997. "Regime Uncertainty: Why the Great Depression Lasted so Long and Why Prosperity Resumed After the War” The Independent Review 1, pp. 561-590.

Higgs, Robert. 2012. "Regime Uncertainty: Some Clarifications.” Mises Daily. Monday, November 19, 2012. http://mises.org/daily/6275/Regime-Uncertainty-SomeClarifications

Jovanovic, Boyan, and Peter L. Rousseau. 2002. “The Q-Theory of Mergers” The American Economic Review 92, pp. 198-204.

Klein, Peter G. 1999. “Entrepreneurship and Corporate Governance.” The Quarterly Journal of Austrian Economics 2, pp. 19-42.

Mises, Ludwig von. 1998. Human Action, Scholar's Edition. Auburn, Ala.: Ludwig von Mises Institute.

Rhodes-Kropf, Matthew, and S. Viswanathan. 2004. "Market Valuation and Merger Waves” The Journal of Finance 59, pp. 2685-2718. 
Rhodes-Kropf, Matthew, David T. Robinson, and S. Viswanathan. 2005. "Valuation Waves and Merger Activity: The Empirical Evidence.” Journal of Financial Economics 77, pp. 561-603.

Rothbard, Murray, N. 1991. “The End of Socialism and the Calculation Debate Revisited.” The Review of Austrian Economics 5, pp. 51-76.

Rothbard, Murray N. 2009. Man, Economy, and State with Power and Market, Scholar's Edition. Auburn, Ala.: Ludwig von Mises Institute.

Salerno, Joseph T. 2012. “A Reformulation of Austrian Business Cycle Theory in Light of the Financial Crisis.” Quarterly Journal of Austrian Economics 15, pp. 3-44.

Shleifer, Andrei and Robert W. Vishny. 2003. "Stock Market Driven Acquisitions.” Journal of Financial Economics 70, pp. 295-311

Thornton, Mark. 2013. “Only Austrian Theory can Explain and Expose Booms and Bubbles.” Mises Daily. Friday, September 13, 2013. http://mises.org/daily/6533/Only$\underline{\text { Austrian-Theory-Can-Explain-and-Expose-Booms-and-Bubbles }}$ 


\section{FIGURES}
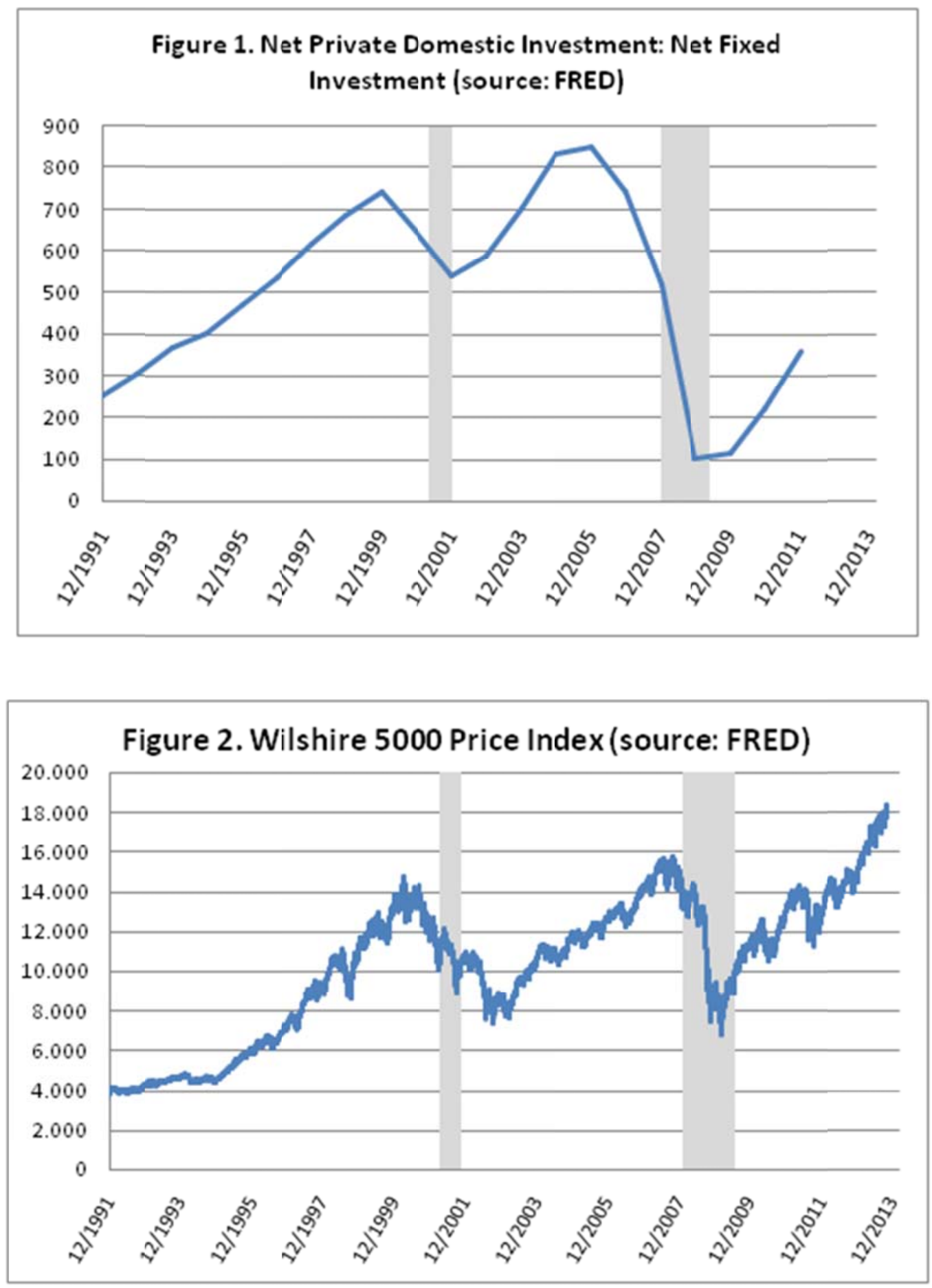

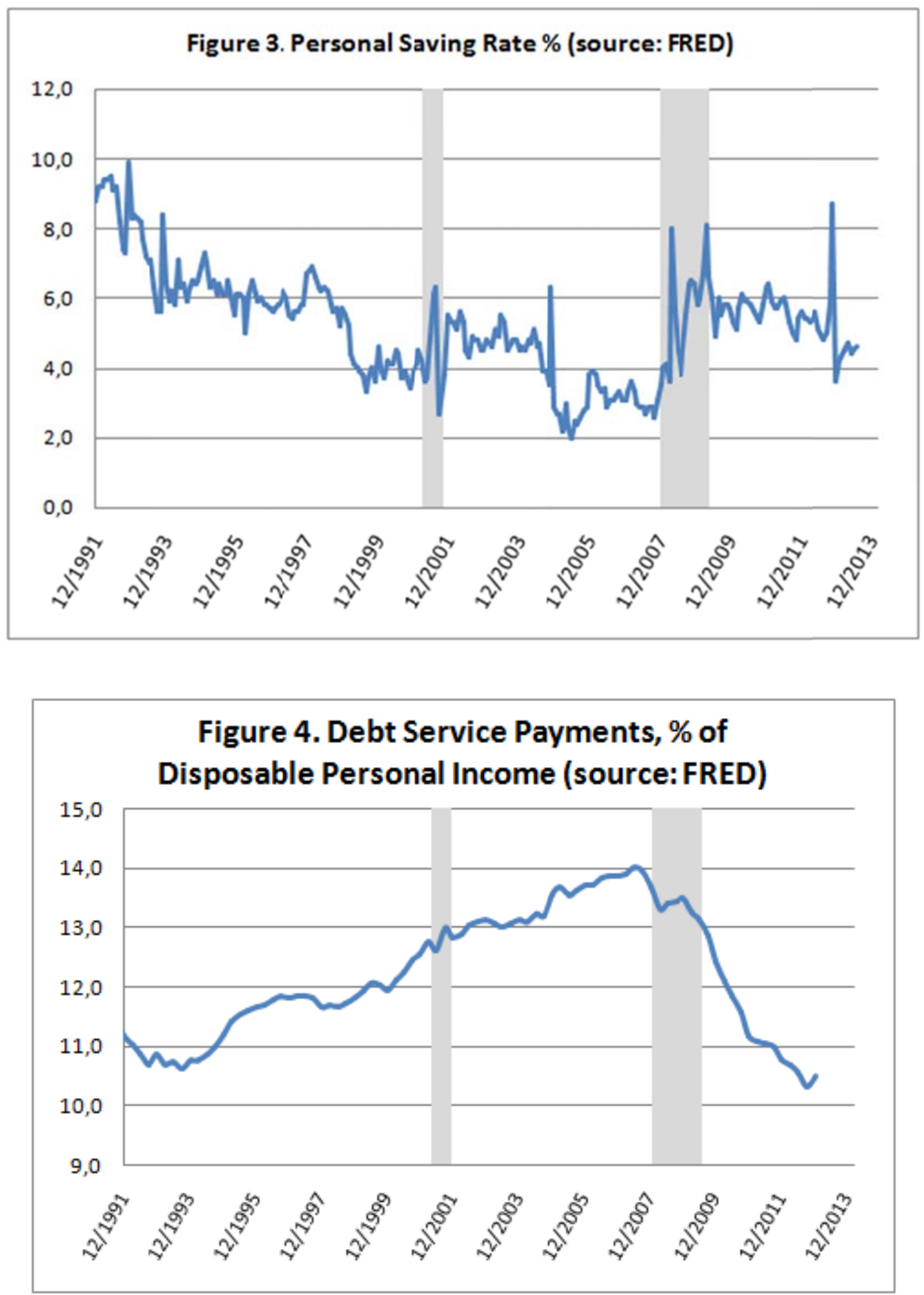

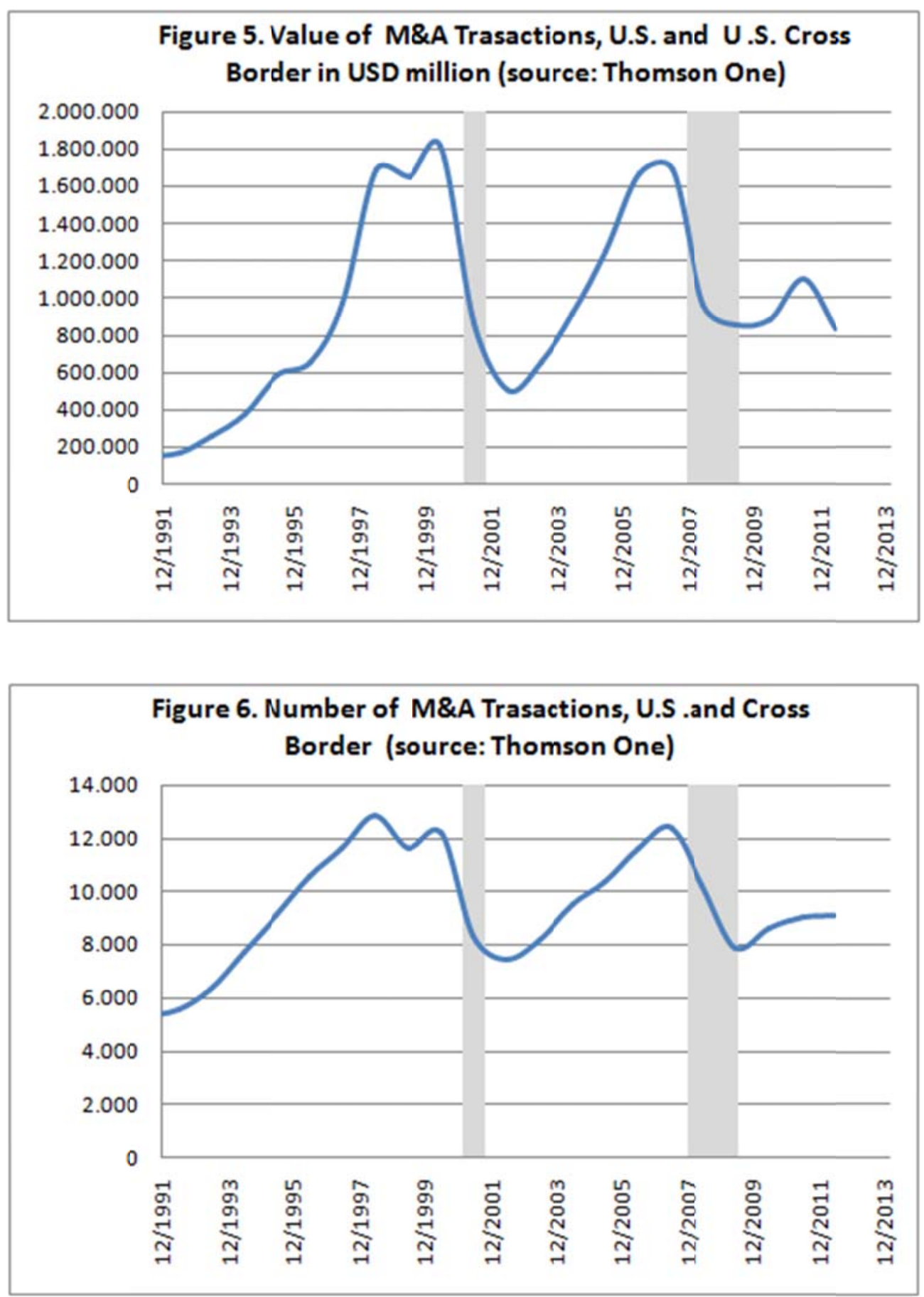

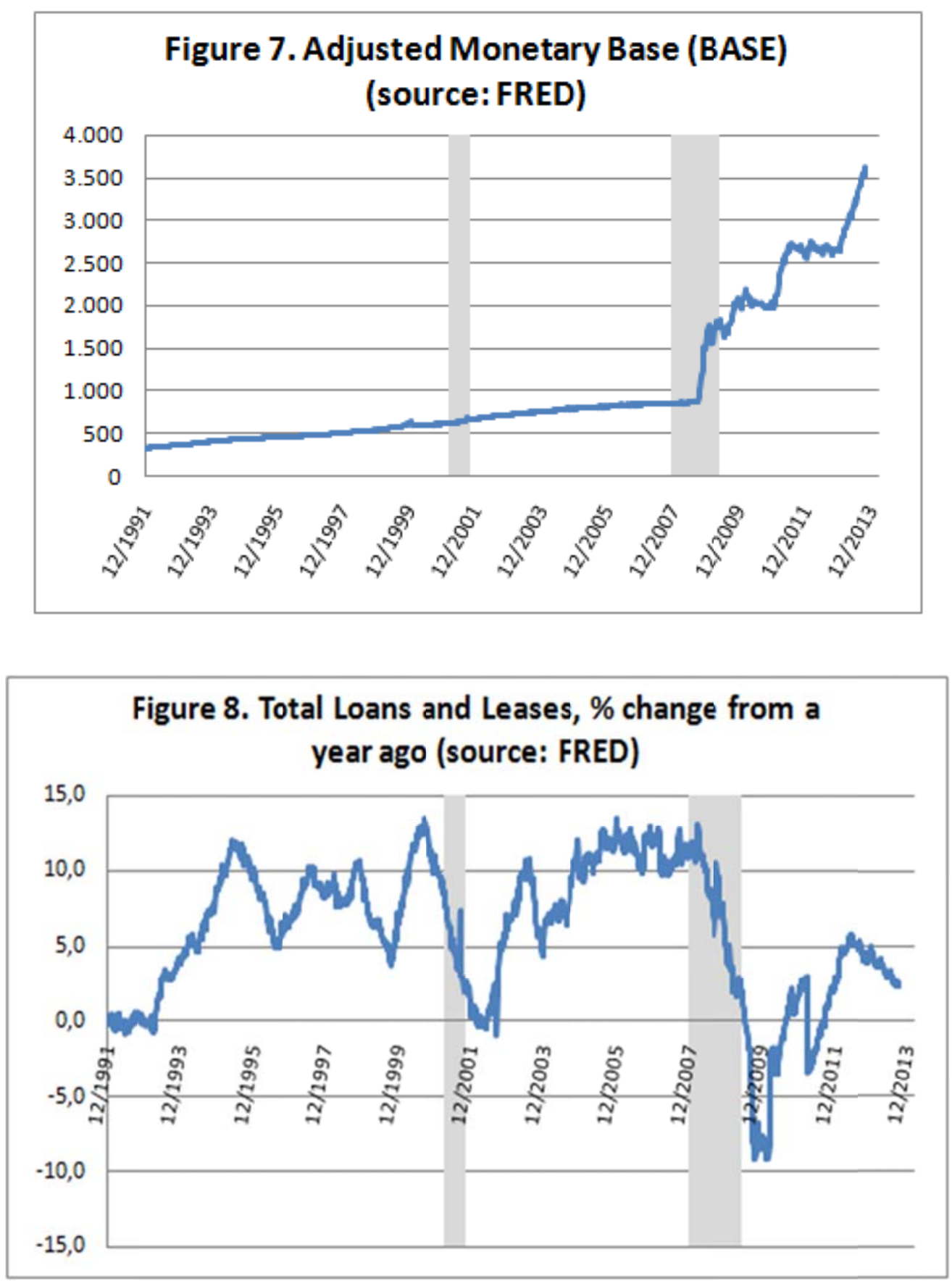